\title{
Impact of Fly Ash on Germination and Initial Seedling Growth Performance of Acacia auriculiformis A. Cunn. Ex Benth
}

\author{
Madhab Chandra Behera*, Anil Kumar Acharya, Manas Ranjan Kar \\ and Maoj Kumar Tripathy
}

Department of Natural Resource Management, College of Forestry, OUAT, Bhubaneswar, Odisha, India-751003

*Corresponding author

\section{A B S T R A C T}

\begin{tabular}{l} 
K e y w o r d s \\
$\begin{array}{l}\text { Forest Nursery, Fly } \\
\text { ash in plantation, } \\
\text { Germination } \\
\text { catalyst, Pollution } \\
\text { control, Seedling } \\
\text { quality index, Solid } \\
\text { waste management }\end{array}$ \\
\hline Article Info \\
\hline $\begin{array}{l}\text { Accepted: } \\
\text { 22 June } 2020 \\
\text { Available Online: } \\
\text { 10 July } 2020\end{array}$ \\
\hline
\end{tabular}

Impact of fly ash (FA) on germination and initial seedling growth performance of Acacia auriculiformis was studied. Growing media was prepared by mixing FA to forest soil (S) at five concentrations 20\%, 40\%, 60\%, 80\% and 100\% (w/w). The experimental design was CRD with six treatments and three replications. Freshly collected seeds were treated with warm water followed by cold water and sown at 1.0-2.0 cm depth in germination trays filled with media of different treatments. Significant $(\mathrm{P}<0.05)$ variation in germination $(\mathrm{G})$ period, G. rate, G. capacity and G. Index with respect to FA concentration in media was observed $(\mathrm{n}=100)$. Maximum $\mathrm{G}$. rate $(84.49 \%)$ and $\mathrm{G}$. index (25.94) were found in media having $20 \%$ FA $\left(\mathrm{T}_{1}\right)$ after 30 days of sowing. After 90 days of transplanting in poly pots containing the mentioned substrates, significant difference $(\mathrm{P}>0.05)$ in seedling survival rate, plant height, diameter growth, leaf number, nodules per plant and seedling quality index were observed. The survival rate $(83.24 \%)$, plant height $(68.87 \mathrm{~cm})$, collar diameter $(0.83 \mathrm{~cm})$, root length $(39.00 \mathrm{~cm})$, nodule number per plant (24.16) and seedling quality index (0.88) were at maximum in growing media having $40 \%$ FA $\left(\mathrm{T}_{2}\right)$. It is concluded form the present investigation that FA can be admixed @ 20\% (w/w) in forest nurseries for improving germination and @40\% (w/w) for promoting seedling growth and quality improvement of Acacia auriculiformis.

\section{Introduction}

Fly ash (FA) is one of the major solid industrial wastes of concern in this twenty first century. It is being generated from coal fired thermal power plants which are the backbone of electricity supply in the world. In India lignite grade is primarily used and it generates about $30-45 \%$ ash as compared to imported high quality coal which has low ash content in the order of $10-15 \%$. As a result huge quantities of FA are being produced at thermal power stations requiring large area of precious land for proper disposal. India ranks fourth in the world in the production of coal ash as by-product waste after USSR, USA and China, in that order (Senapati, 2011). 196.44million tons of Fly ash is being generated from 167 thermal power stations, during the year 2017-18. Tough there is a 
stringent government regulation for cent percent utilization of FA, only $67.13 \%$ have been utilized (CEA 2018).

FA contains a number of toxic metals such as arsenic (As), barium (Ba), mercury $(\mathrm{Hg})$, cadmium (Cd), selenium (Se), chromium $(\mathrm{Cr})$, nickel $(\mathrm{Ni})$, vanadium $(\mathrm{V})$, lead $(\mathrm{Pb})$ and zinc $(\mathrm{Zn})$ depending upon the source of coal (Dwivedi and Jain, 2014). Proper disposal and management of such a huge quantity of FA possessing potential threats of air and water soil pollution is a great challenge (Rawat et al., 2018). Utilization of FA for a particular purpose depends up on its elemental content which is primarily controlled by type of coal and its source. FA is being used in manufacturing cement, concrete, bricks, wood substitute products, in road construction, wasteland reclamation; filling of underground mine spoils (Kaur and Goyal, 2015). In India major sectors include construction of roads and embankments, production of cement, mine-filling, reclamation of low-lying areas, making bricks and tiles (Environment Annual Reports, 2014-15).

FA contains almost all the plant nutrients except nitrogen, phosphorous and humus, which can be supplemented by organic matter (Sharma and Karla 2006). Hence there is a scope for utilization in agriculture and forestry sector. Many research findings infers to the positive growth and nutritional efficiency of FA. Crop plants of the families Brassicaceae, Chenopodiaceae, Fabiaceae, Leguminoceae and Poaceae are most tolerant to FA toxicity (Cheung et al., 2000). Low bulk density, high water holding capacity and porosity, rich silt-sized particles, alkaline nature, negligible solubility of Indian FA makes it a better choice for reclamation material for wasteland and mine overburden soils. Still then a large quantity of FA is being dumped up in ash ponds and lagoons. Some of the FA contains deadliest toxic metals like
As, $\mathrm{Hg}, \mathrm{Cd}, \mathrm{Cr}$ and Se. These toxic metals along with other toxicants can cause cancer and neurological damage in human. They can also harm and kill wildlife, especially fish and other water-dwelling species (Ahmad et al., 2014). The current status of utilization of FA in India is only $60-70 \%$ (CEA, 2018), providing a wide scope for searching new avenues.

One of the most potential areas of utilization is in forestry sector where it can be consumed either in nursery or for tree plantation activities. This will help in locking the toxic heavy metals in the wood biomass for longer period of time. FA as planting material in forest nursery is not a new concept. Goyal et al., (2002) reported its use in nursery as growing media but commercial use is scanty or absent. Hence attempt is made to know its impact on seed germination and growth of seedlings at early stages.

Acacia auriculiformis (Fabaceae) commonly known as earleaf acacia was selected because of its nitrogen fixing ability, rapid growth potential and diverse ecological significance. It is an important species for social and agroforestry plantation. Tolerance in infertile, acid, alkaline or seasonal waterlogged soil, mine overburden soil makes it very useful species for reclamation purpose.

\section{Materials and Methods}

The experiment was conducted in College of Forestry, Odisha University of Agriculture and Technology, Bhubaneswar situated at $20^{\circ}$ $15^{\prime} \mathrm{N}$ latitude and $85^{\circ} 52^{\prime} \mathrm{E}$ longitude with altitude $25.9 \mathrm{~m}$ amsl. FA was collected from one of the silages of Indian Metals and Ferro Alloys (IMFA) Limited, Choudwar, Cuttack (Odisha). The mean monthly temperature, relative humidity and rainfall of the experimental site is given in Fig.1. 
Growing media preparation and analysis for physicochemical properties

Growing media was prepared by mixing FA to forest soil (S) at concentrations $20 \%, 40 \%$, $60 \%, 80 \%$ and $100 \% \mathrm{~W} / \mathrm{W}$. There were six treatments $\left(\mathrm{T}_{1}-20 \% \mathrm{FA}+\mathrm{S}, \mathrm{T}_{2}-40 \% \mathrm{FA}+\mathrm{S}, \mathrm{T}_{3}-\right.$ $\left.60 \% \mathrm{FA}+\mathrm{S}, \mathrm{T}_{4}-80 \% \mathrm{FA}+\mathrm{S}, \mathrm{T}_{5}-100 \% \mathrm{FA}\right)$ including control $\left(\mathrm{T}_{6}-\mathrm{S}\right)$. The growing media was analysed for physical and chemical properties. Bulk density (BD) and water holding capacity (WHC) was determined by using the protocol given by Piper (1966). $\mathrm{pH}$ and electrical conductivity (EC) were measured following protocol given by Jackson (1967), organic carbon (OC) was estimated as per Walkley and Black (1934). Available nitrogen, phosphorus and ammonium acetate extractable potassium were estimated as per the procedure given by Subbiah and Asija (1956), Olsen et al., (1954) and Merwin and Peech (1951) respectively. The physical and chemical properties of growing media are given in table-1.

\section{Seed treatment and sowing}

Freshly collected seeds were given hot water treatment prior to sowing. Seeds were soaked in warm water at $80^{\circ} \mathrm{C}$ for 10 minutes followed by cold water treatment for 24 hours (Azad et al., 2011). Eighteen germination trays having dimension $90 \mathrm{~cm}$ (L) $\times 45 \mathrm{~cm}$ (B) $\times 15 \mathrm{~cm}(\mathrm{H})$ were filled with above six mentioned growing media to the brim leaving $3.0 \mathrm{~cm}$. Hundred seeds per replication (totalling 300 seeds per treatment) were sown at 1.0-2.0 $\mathrm{cm}$ depth, covered with paddy straw and kept at open nursery condition. Regular watering was made during morning hours as per the requirement. Observations pertaining to germination parameters were recorded daily up to 30 days after sowing. Germination period was determined by observing the day taken for first germination (DTFG) to $30^{\text {th }}$ day when about $80-85 \%$ seeds have germinated.
Based on the number of seeds germinated the following parameters were calculated as per the standards given by Czabatore (1962) and AOSA (1983).

$$
\text { Germination } \%=\frac{\text { Number of seeds germinated }}{\text { Number of seeds sown }} \times 100
$$

Germinationcapacity $=\frac{\text { Total seeds germinated }+ \text { viable seeds }}{\text { Total No of seeds sown in all replications }} \mathrm{X} 100$

$$
\text { GerminationValue }=\text { PV } \times \text { MDG }
$$

Where, $\mathrm{PV}=$ Peak value of Germination

Germination

GerminationIndex $=\frac{\text { No.of Germinated seed }}{\text { Days of first count }}+\cdots \cdots \cdots+\frac{\text { No.Germinated seed }}{\text { Days of Final Count }}$

\section{Seedling growth and quality}

After completion of germination study, seedlings were transplanted into poly pots $(22.86 \times 12.7 \mathrm{~cm})$ containing growing media of above mentioned treatment combinations. Growth parameters such as shoot length, collar diameter and number of leaves were assessed monthly after 30 days of transplanting for 3 months. Total shoot length was measured by using ruler (taken from the apical bud of the plant to the base of the shoot) and stem diameter by using electronic digital calliper $(6 " / 150 \mathrm{~mm}$, accuracy \pm 0.01 mm, Mitutoyo- CD-6"ASX:500-196-30).

For recording the quantitative parameters pertaining to root growth, the entire seedling was dipped in a bucket of water at 90 days to remove adhering soil from it. It was then carefully washed so that no damage was made to root system. Length of roots (starting from collar region to the end point) and number of root nodules were recorded. Thoroughly washed seedlings (without damage to root and shoot) were dried under sun for 30 minutes. 
The shoot was cut from the collar portion and weighed. Then the root and shoot sample were put in paper bags separately and were oven dried at $80^{\circ} \mathrm{C}$ until constant weight observed. Growth observation was based on 45 numbers of randomly selected plants from each treatment. The seedling quality index (SQI) was calculated by using the formula as described by Dickson et al., (1960).

SQI $=$ Seedling dry wt. $(\mathrm{gm}) /\left[\frac{\text { Height }(\mathrm{cm})}{\text { Diameter }(\mathrm{mm})}+\frac{\text { Shoot dry Wt. }(\mathrm{gm})}{\text { Root dry Wt. }(\mathrm{gm})}\right]$

The experiment was completely randomized design (CRD) with six treatments and three replications. The collected data were analysed by using SPSS software version 20 for windows operating system. Analysis of variance (ANOVA) was carried out to determine the treatments effect on seed germination and early seedling growth. Means were analysed according to the Duncan Multiple Range Test (DMRT) at $\mathrm{P}<$ 0.05 (Duncan 1955).

\section{Results and Discussion}

Fly ash is a noxious solid waste seeking proper disposal and management. It has some multifarious utility. Still ample amount left unutilised at disposal sites of thermal power plants polluting air and water. There exists a vast scope for utility in forestry sector as potting mixture ingredient and soil improvement material at difficult sites prior to plantation. The matrix of application depends upon the elemental composition of FA to be used, tolerance limit of plant species selected and physiochemical property of plantation site soil or growing media in which FA need to be added. Fertility status of poor degraded waste lands and problematic soils are successfully improved by FA addition to varying degrees in different agro-climatic situation. Enhancement in crop yield and vegetative growth tree species have been reported by many workers when applied judiciously (Kumar et al., 2002, Sinha et al., 2005, Ramesh et al., 2008, Chaudhary et al., 2009, and Krzaklewski et al., 2012, Behera et al., 2018.)

\section{Effect of substrate on seed germination}

A success of plantation programs needs uninterrupted supply of quality seedlings. Growth media have a profound impact on germination and subsequent growth of embryo. Seedlings raised on good media ensure better establishment and growth when planted to the main field. The ultimate advantage of a suitable substrate is good drainage, water holding capacity and adequate supply of nutrients thereby, producing excellent disease-free seedlings (Noble 1993). Substrate property especially $\mathrm{pH}$ and water retention capacity have a marked impact on germination. $\mathrm{pH}$ affects germination either by increasing the osmotic pressure of the media to a plant that will retard or prevent the intake of water or by causing toxicity to the embryo (Rashid 2004).

The present study indicates that, FA have a significant $(\mathrm{P}<0.05)$ impact on seed germination parameters like g. period, g. rate, g. capacity and g. index, however did not have any impact on the number of days taken for first germination (NDFG) and germination value (Table 2). Addition of FA to growing media reduced germination period in a dosedepended manner due to an increase in $\mathrm{pH}$ towards alkalinity. Similar type of observations was reported by Behera et al., (2020) in Leucaena leucocephala.

The highest seed germination rate $(84.49 \%)$ was observed in substrate having $20 \%$ fly ash $\left(\mathrm{T}_{1}\right)$ and statistically at par with $(\mathrm{P}>0.05)$ treatment $\mathrm{T}_{2}(80.02 \%)$. The germination rate of $77.40 \%$ in $\mathrm{T}_{3}$ and $75.00 \%$ in control $\left(\mathrm{T}_{6}\right)$ are statistically at par $(\mathrm{P}>0.05)$ with each 
other. Minimum germination rate $(64.65 \%)$ was observed in substrate having $100 \%$ FA $\left(\mathrm{T}_{5}\right.$, Table-2). The increased germination rate $(84.49 \%)$ in $20 \%$ FA admixed growing media was attributed to the improvement in the physicochemical condition of germinating media over control (75.00\%, Table-2). Azad et al., (2011) reported maximum $83.75 \pm 1.25 \%$ germination for hot water treatment (Immersion in hot water at $80^{\circ} \mathrm{C}$ for $10 \mathrm{~min}$ ) of seeds of $A$. auriculiformis. The reduction in germination rate beyond $20 \%$ FA addition $(\mathrm{w} / \mathrm{w})$ in media was due to enhanced $\mathrm{pH}$ and elemental toxicity. Higher $\mathrm{pH}$ and metals like $\mathrm{Cu}^{2+}, \mathrm{Zn}^{2+}$ at higher $\mathrm{EC}$ are reported toxic to embryo and reduces biological activity during germination process (Gupta et al., 2000). There existed negative relationship between FA rate with germination percentage, germination capacity but it was positive with DTFG, germination period and germinative index (Table-2).

\section{Effect of substrate on seedling growth}

After 90 days of transplanting significant difference $(\mathrm{P}>0.05)$ in survival rate, plant height, diameter growth, number of leaves, mean root length, nodules per plant and seedling quality index of $A$. auriculiformis was observed (Table-3).

Highest seedling survival rate $(83.24 \%)$ was found in substrate containing $40 \% \mathrm{FA}\left(\mathrm{T}_{2}\right)$ which was statistically $(\mathrm{P}>0.05)$ indifferent from treatment $\mathrm{T}_{1}(81.83 \%), \mathrm{T}_{3}(79.80 \%)$ and control $(80.93 \%)$. The maximum survival rate $(83.24 \%)$ of seedlings in substrate containing $40 \% \mathrm{FA}\left(\mathrm{T}_{2}\right)$ was due the improved aeration, water retention capacity and favourable $\mathrm{pH}$ of substrate (Table-1). The survival rate decreased linearly with increased concentration of FA up to minimum $46.57 \%$ in growth media having 100\% FA (Table-3).

Table.1 Physicochemical properties of fly ash, forest soil and fly ash substratum

\begin{tabular}{|c|c|c|c|c|c|c|}
\hline \multirow[t]{2}{*}{ Property } & \multirow{2}{*}{$\begin{array}{c}\text { Forest } \\
\text { Soil } \\
\text { (S) }\end{array}$} & \multirow{2}{*}{$\begin{array}{l}\text { Fly ash } \\
\text { (FA) }\end{array}$} & \multicolumn{4}{|c|}{ FA substrate (Forest soil + FA \% (w/w)) } \\
\hline & & & $\begin{array}{c}\mathrm{S}+ \\
20 \% \mathrm{FA}\end{array}$ & $\begin{array}{c}\mathrm{S}+ \\
40 \% \mathrm{FA}\end{array}$ & $\begin{array}{c}\mathrm{S}+ \\
60 \% \mathrm{FA}\end{array}$ & $\begin{array}{c}\mathrm{S}+ \\
80 \% \mathrm{FA}\end{array}$ \\
\hline pH & 6.97 & 7.67 & 7.06 & 7.26 & 7.32 & 7.45 \\
\hline $\mathrm{EC}\left(\mathrm{dS} \mathrm{m}^{-1}\right)$ & 0.684 & 0.212 & 0.230 & 0.265 & 0.311 & 0.476 \\
\hline $\mathbf{N}\left(\mathbf{k g ~ h a ~}^{-1}\right)$ & 0.002 & 125.50 & 106.15 & 98.67 & 82.50 & 37.50 \\
\hline$P\left(k_{g ~ h a}{ }^{-1}\right)$ & 6.70 & 56.13 & 48.23 & 36.92 & 20.58 & 14.69 \\
\hline $\mathrm{K}\left(\mathrm{kg} \mathrm{ha}^{-1}\right)$ & 146.43 & 474.36 & 496.41 & 509.92 & 546.2 & 613.15 \\
\hline $\mathrm{OC}(\%)$ & 0.005 & 0.570 & 0.519 & 0.464 & 0.382 & 0.261 \\
\hline $\mathrm{BD}\left(\mathrm{g} \mathrm{cm}^{-3}\right)$ & 0.69 & 1.48 & 1.41 & 1.24 & 0.95 & 0.76 \\
\hline $\begin{array}{l}\text { Pore space } \\
(\%)\end{array}$ & 49.52 & 32.8 & 43.2 & 46.4 & 48.25 & 49.35 \\
\hline WHC (\%) & 58.2 & 41.0 & 43.25 & 45.84 & 48.72 & 54.33 \\
\hline
\end{tabular}

Values are Mean (N=Arithmetic mean); FA- fly ash; S- Forest Soil, EC- Electrical conductivity, NPK-Available Nitrogen, Phosphorous and Potash, OC-Organic carbon, BD-Bulk density, WHC-Water holding capacity. 
Table.2 Effects of substrates on germination of A. auriculiformis seeds at 30 days after sowing

\begin{tabular}{|c|c|c|c|c|c|c|}
\hline $\begin{array}{l}\text { Parameters } \rightarrow \\
\text { Treatments } \downarrow\end{array}$ & DTFG & G. Period & GP (\%) & GC & GV & GI \\
\hline $\mathbf{T}_{1}$ & $9.0_{\mathrm{b}}$ & $11.33_{\mathbf{a b}}$ & $84.49_{\mathrm{d}}$ & $87.98_{\mathbf{d}}$ & $69.67 \mathrm{c}$ & $25.94 \mathrm{c}$ \\
\hline $\mathbf{T}_{2}$ & $8.67_{b}$ & $11.0_{\mathrm{ab}}$ & $80.02_{\text {cd }}$ & $84.20_{\text {cd }}$ & 60.39 bc & $23.67 \mathrm{bc}$ \\
\hline $\mathbf{T}_{3}$ & $7.67 \mathbf{a b}$ & $10.0_{\mathrm{a}}$ & $77.40 \mathrm{bc}$ & 80.54 bc & $56.80_{\text {abc }}$ & $20.98_{\text {ab }}$ \\
\hline $\mathbf{T}_{4}$ & $7.33_{\mathrm{ab}}$ & $9.0_{\mathrm{a}}$ & $72.38_{\mathbf{b}}$ & $74.61_{\mathbf{b}}$ & 50.29 ab & $20.78_{\mathbf{a b}}$ \\
\hline $\mathbf{T}_{\mathbf{5}}$ & $5.67 \mathrm{~b}$ & $8.0_{\mathrm{a}}$ & $64.65_{\mathrm{a}}$ & $66.52 \mathrm{a}$ & $42.67 \mathrm{a}$ & $21.43_{\mathbf{a b}}$ \\
\hline $\mathbf{T}_{6}$ & $12.33_{c}$ & $14.0_{b}$ & $75.00_{\mathrm{bc}}$ & $78.83_{\text {bc }}$ & $48.07 \mathrm{ab}$ & $18.45_{a}$ \\
\hline \multicolumn{7}{|c|}{ Statistical analysis } \\
\hline$P(\mathbf{0 . 0 5})$ & 0.005 & 0.12 & 0.001 & 0.008 & 0.14 & 0.004 \\
\hline SE & 0.56 & 0.58 & 1.69 & 1.83 & 1.64 & 0.67 \\
\hline $\mathbf{F}$ & 0.67 & 4.30 & 9.72 & 11.66 & 4.67 & 6.5 \\
\hline \multicolumn{7}{|c|}{ Linear Regression analysis ( $y=$ concerned parameter, $x=$ FA rate) } \\
\hline $\mathbf{y}=$ & $12.14-.82 \mathrm{x}$ & 13.27 & $80.12-.44 x$ & $84.18-.49 x$ & $57.31-.16 x$ & $20.70-.28 x$ \\
\hline tments & & $\mathrm{T}_{2}=(40 \%$ & S), $\quad \mathrm{T}_{3}=(60 \%$ & $\mathrm{FA}+\mathrm{S}), \quad \mathrm{T}_{4}=(8$ & $\% \quad \mathrm{FA}+\mathrm{S}), \quad \mathrm{T}$ & $=(100 \%$ FA $)$ \\
\hline
\end{tabular}

Table.3 Effects of substrate on growth and quality of Acacia auriculiformis seedlings at 90 DAT

\begin{tabular}{|c|c|c|c|c|c|c|c|}
\hline $\begin{array}{l}\text { Parameters } \rightarrow \\
\text { Treatments } \downarrow\end{array}$ & $\begin{array}{c}\text { Surviva } \\
I(\%)\end{array}$ & $\begin{array}{c}\text { Plant } \\
\text { height } \\
(\mathbf{c m})\end{array}$ & $\begin{array}{c}\text { Collar } \\
\text { diameter } \\
(\mathbf{c m})\end{array}$ & $\begin{array}{l}\text { Number } \\
\text { of leaves }\end{array}$ & $\begin{array}{l}\text { Mean } \\
\text { root } \\
\text { length } \\
(\mathrm{cm})\end{array}$ & $\begin{array}{c}\text { Nodules/ } \\
\text { Plant } \\
\text { (No.) }\end{array}$ & SQI \\
\hline $\mathbf{T}_{1}$ & $81.83_{b}$ & $53.43_{b}$ & $0.47 \mathrm{a}$ & $24.27_{b}$ & $26.24_{b}$ & $12.60_{\mathrm{a}}$ & $0.26_{\mathrm{ab}}$ \\
\hline $\mathbf{T}_{2}$ & $83.24_{b}$ & $68.87 \mathrm{c}$ & $0.83_{\mathbf{b}}$ & $42.51_{d}$ & $39.00_{c}$ & $24.16_{c}$ & $0.88_{\mathbf{c}}$ \\
\hline $\mathbf{T}_{3}$ & $79.80_{b}$ & $63.70_{c}$ & $0.78_{b}$ & $35.32 \mathrm{c}$ & $21.77_{a b}$ & $14.30_{b}$ & $0.77 \mathbf{c}$ \\
\hline $\mathbf{T}_{4}$ & $56.97 \mathrm{a}$ & $45.77_{\mathbf{b}}$ & $0.53 \mathrm{a}$ & $18.79_{a b}$ & $17.87_{\mathbf{a b}}$ & $8.30_{a}$ & $0.51_{b}$ \\
\hline $\mathbf{T}_{5}$ & $46.57_{\mathrm{a}}$ & $36.51_{\mathrm{a}}$ & $0.50 \mathrm{a}$ & $14.79_{\mathrm{a}}$ & $13.76_{\mathrm{a}}$ & $2.30_{\mathrm{a}}$ & $0.22 \mathrm{a}$ \\
\hline$T_{6}$ & $80.93_{b}$ & $52.10_{b}$ & $0.44 \mathrm{a}$ & $21.28_{a b}$ & $26.00_{b}$ & $10.30_{a b}$ & $0.24 \mathrm{ab}$ \\
\hline \multicolumn{8}{|c|}{ Statistical analysis } \\
\hline $\mathbf{P}(\mathbf{0 . 0 5})$ & 0.002 & 0.004 & 0.006 & 0.01 & 0.006 & 0.001 & 0.007 \\
\hline SE & 3.76 & 2.7 & 0.04 & 2.4 & 2.29 & 2.16 & 0.06 \\
\hline $\mathbf{F}$ & 14.15 & 19.69 & 1.8 & 16.73 & 5.8 & 8.9 & 2.3 \\
\hline \multicolumn{8}{|c|}{ Linear Regression analysis $(y=$ concerned parameter, $x=$ FA rate) } \\
\hline $\mathbf{y}=$ & $89.40-.79 \mathrm{x}$ & $60.43-.42 x$ & $0.56+.11 \mathrm{x}$ & $29.56-023 \mathrm{x}$ & $26.8-0.2 \mathrm{x}$ & $10.3-13 x$ & $0.45+.08 x$ \\
\hline
\end{tabular}

Treatments $\mathrm{T}_{1}=(20 \% \mathrm{FA}+\mathrm{S}), \mathrm{T}_{2}=(40 \% \mathrm{FA}+\mathrm{S}), \mathrm{T}_{3}=(60 \% \mathrm{FA}+\mathrm{S}), \mathrm{T}_{4}=(80 \% \mathrm{FA}+\mathrm{S}), \mathrm{T}_{5}=(100 \% \mathrm{FA}), \mathrm{T}_{6}=(\mathrm{S} /$ Control), FA- fly ash, S- Forest Soil, SQI-Seedling Quality Index, Mean values followed by same letter are statistically indifferent. 
Fig.1 Climatic parameters of the experimental site

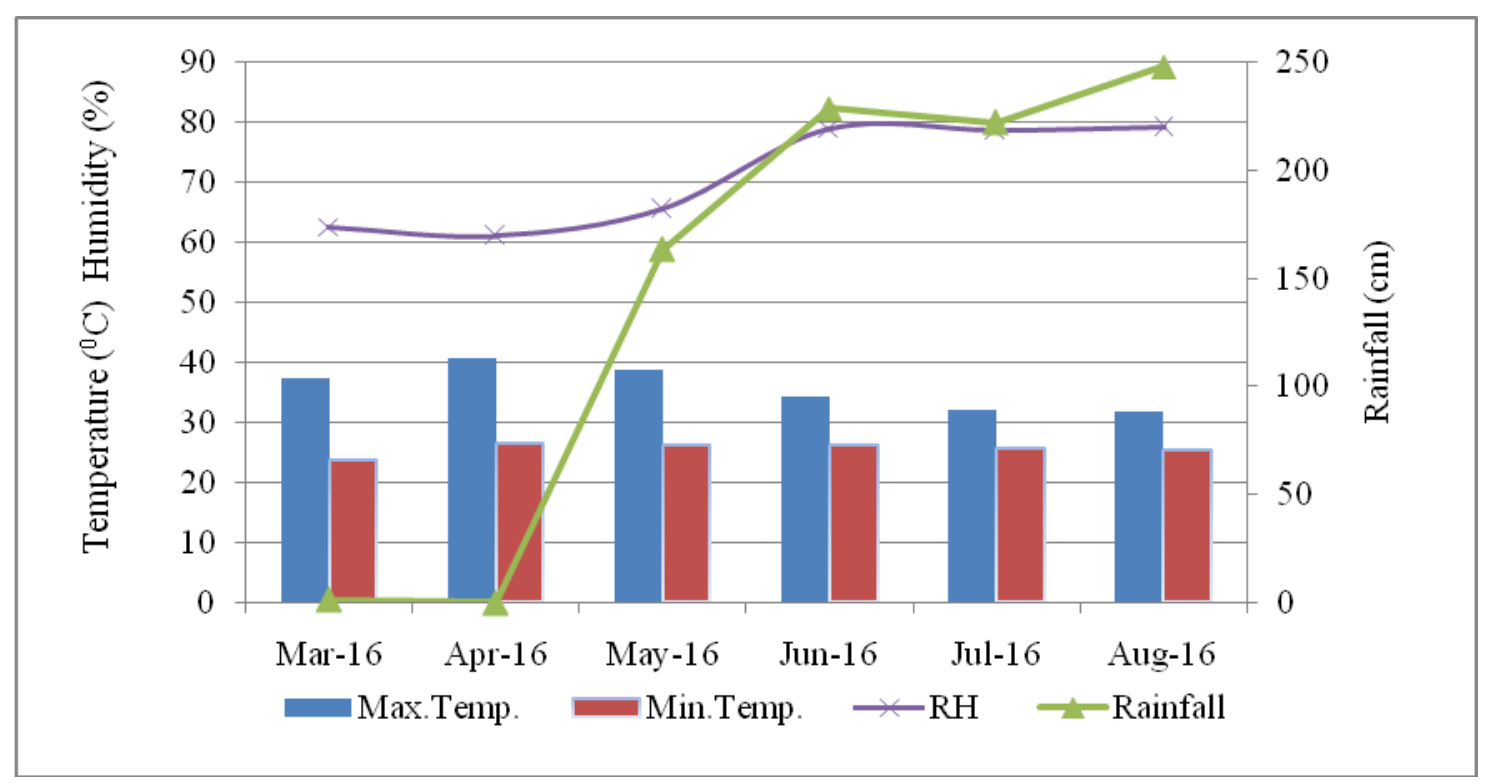

The maximum height $(68.87 \mathrm{~cm})$ was found in treatment having $40 \% \mathrm{FA}\left(\mathrm{T}_{2}\right)$ and it was statistically at par with Treatment $\mathrm{T}_{3}(63.70$ $\mathrm{cm})$. The diameter growth was maximum in treatment $T_{2}(0.83 \mathrm{~cm})$ and statistically at par with $\mathrm{T}_{3}(0.78 \mathrm{~cm})$. The number of leaves (42.51), mean root length $(39.00 \mathrm{~cm})$ and nodules per plant (24.16) was significantly higher in treatment $T_{2}$. The seedling quality index in treatment $\mathrm{T}_{2}(0.88)$ and treatment $\mathrm{T}_{3}$ (0.77) were statistically at par with each other. A similar trend in growth of seedlings with respect to FA concentration was reported by Gupta et al., (2000) and Pandey et al., (1996).

The vigour in seedling height, diameter and root growth of this species at $40 \%$ FA was due to optimum $\mathrm{pH}$, improvement in availability of nutrients in ionic form at rhizosphere solum, improved nitrogen fixation rate (Table -2) and reduced or no attack of nursery insect and pest. Goyal et al., (2002) observed 10\% increase in the growth of Eucalyptus tereticornis, Acacia auriculiformis and Casuarina equisetifolia during early 6 months, grown in FA amended soils (ESP FA@18-24\% (v/v)). Good root nodulation per plants (24.16) in substrates having $40 \%$ FA could be attributed due to uptake of optimum amount of metals by the roots. However, the nodulation rate decreased after $40 \%$ FA linearly up to $100 \%$ FA which is due to the reduced ability of nitrogen fixing bacteria with increasing stress level (Faizan and Kaushar 2010). The depressive nodulation effect was substantiated by reduced plant height, collar diameter growth and SQI. Further the plants grown in 40\% FA were observed to be very healthy. Better seedling quality index in $\mathrm{T}_{2}(0.88)$ was obviously due to the improved availability of micronutrients that supported higher biomass production and shoot: root ratio (Gupta et al., 2000). Ariful Islam et al., (2019) observed seedling quality index in the range of 0.611.81 for Acacia auriculiformis after eight months grown on different substrates. The present SQI after three months of transplanting is within that range.

In conclusion, A. auriculiformis is a rhizobial fast growing multipurpose legume tree species. It is a much common species in social forestry, agroforestry, multipurpose wood lots and energy plantations of India. Robust quality seedlings not only ensure successful 
planting action but also reduce beating up cost. The results of present investigation recommends FA should be admixed at $20 \%$ $(w / w)$ level in nursery beds for early sprouting and improving germination percentage. However it should be admixed at $40 \%$ in potting mixture for production of healthy and quality planting material. Further study is necessary to quantify the economic benefit or net profit gain from utilizing FA in forest nursery.

\section{Acknowledgement}

We express our deep sense of gratitude to Dean, College of Forestry, OUAT, Bhubaneswar (Odisha) for his valuable guidance, support and encouragement during the entire period of research.

\section{References}

Ahmad, M. A., Shahnawaz M, Siddiqui M. F., Khan, Z. H. 2014. A Statistical Review on the current scenario of generation and utilization of fly-ash in India. International Journal of Current Engineering and Technology, 4(4):2434-2438.

AOSA 1983. Seed vigor testing handbook: Contribution No.32 to the handbook on seed testing, Association of official seed analysts, Lincoln, NE, USA.

Ariful Islam, M.D., Rahman, M.D.R., Hossain, M.D.K. 2019. Effect of container and potting media on raising quality seedlings of Acacia auriculiformis in the nursery. Asian Journal of Agriculture, 3(1):26-32.

Azad, M. S., Manik, M. R., Hasan, M. S. and Matin, M. A. 2011. Effect of different pre sowing treatments on seed germination percentage and growth performance of Acacia auriculiformis. Journal of Forestry Research, 22(2): 183-188.

Behera, M. C., Lachungpa, O and Mohanty, T. L. 2020. Impact of Fly Ash on Germination and Initial Seedling Growth of Leucaena leucocephala (Lam.) De Wit. Indian Journal of Ecology, 47(1): 117-122.

Behera, M. C., Lachungpa, O, Mohanty, T. L. and
Nayak, H. 2018. Eco-friendly utilization of fly ash in forest nursery for quality planting material production of Peltophorum Pterocarpum (DC) K. Heyne. Ecology, Environment and Conservation, 25 (1): 365-372.

Chaudhary, D. R., Ghosh, A., Chikara, J., Patolia, J. S. 2009. Elemental content of three plant species growing on abandoned fly ash landfill. Indian Forester, 135(3): 393-402.

Cheung, K. C., Wong, J. P. Z., Zhang, Z. Q., Wong, J. W. C., Wong, M. H. 2000. Revegetation of lagoon ash using legume species Acacia auriculiformis and Leucaena leucocephala. Environmental Pollution, 109(1):75-82.

Czabator, F. J. 1962. Germination value - an index combining speed and completeness of pine seed germination. Forest Science, 8:386 396.

Dickson, A., Leaf, A. L. and Hosner, J. F. 1960. Quality appraisal of white spruce and white pine seedling stock in nurseries. Forestry Chronicle. 36(1):10-13.

Duncan, D. B. 1955. Multiple Ranges and Multiple F-tests. Biometrics, 11: 1-42.

Dwivedi, A. and Jain, M. K. 2014. Fly ash - waste management and over view: A review. Recent Research in Science and Technology, 6(1):30-35.

Faizan, S. and Kausar, S. 2010. Impact of coal ash on growth, yield, biomass and nodulation of lentil (Lens culinaris). $J r$ of Industrial Pollution Control, 26(2):161-165.

Goyal, D., Kaur, K., Garg, R., Vijayan,V., Nanda, S. K., Nioding, A., Khanna, S., Ramamurthy, V. 2002. Industrial fly ash as a soil amendment agent for raising forestry plantations. TMS Annual Meeting: 251260.

Gupta, M., Kumar, A., Yunus, M. 2000. Effect of fly-ash on metal composition and Physiological responses in Leucaena leucocephala (lam.) de. Wit. Environmental Monitoring and Assessment, 61:399-406.

Jackson, M. L. 1967. Soil chemical analysis, Oxford IBH publishing house, Bombay.

Kaur, R. and Goyal, D. 2015. Mineralogical studies of coal fly ash for soil application in agriculture. Particulate Science and Technology. 33 (1):76-80. 
Kishor, P., Ghosh, A. K. and Kumar, D. 2010. Use of fly ash in agriculture: A way to improve soil fertility and its productivity. Asian Journal of Agricultural Research, 4(1):1-14.

Krzaklewski, W., Pietrzykowski, M. and Wos, B. 2012. Survival and growth of alders (Alnus glutinosa (L.) Gaertn. and Alnus incana (L.) Moench on fly ash technosols at different substrate improvement. Ecological Engineering, 49:35- 40.

Kumar, A., Vajpayee, P., Ali, M. B., Tripathi, R. D., Singh, N., Rai, U. N. and Singh, S. N. 2002. Biochemical responses of Cassia siamea Lamk. grown on coal combustion residue (Fly-ash). Bulletin of Environmental Contamination and Toxicology, 68:675683.

Merwin, H. D. and Peech, M. 1951. Exchangeability of soils potassium in the silt and clay fractions as influenced by the nature of the complimentary exchangeable cations. Soil Science Society of American Proceedings, 15: 125-128.

Noble, P. 1993. Effect of potting mixture on-farm tree seedlings survived in heavy soils. Agroforestry Systems, 21: 75-78.

Olsen, R., Cole, C. V., Watanabe, F. S. and Dean, L. A. 1954. Estimation of available phosphorous by extraction with sodium bicarbonate. USDA Circular. 939:1-19.

Pandey, O. N., Sarkar, A. K. and Sharma, V. N. 1996. Growth of certain tree species in fly ash amended soil. Proceedings, NS-EWM: 183-191

Piper, C. S. 1966. Soil and plant analysis. Hans Publisher, Bombay.

Ramesh, V., Korwar, G. R., Mandal, U. K., Prasad, V. N. S., Sharma, K. L., Yezzu, S.
R. and Kandula, V. 2008. Influence of fly ash mixtures on early tree growth and physicochemical properties of soil in semiarid tropical Alfisols. Agroforestry Systems, 73:13-22.

Rashid, M. M. 2004. Salt Tolerances of some multipurpose tree species as determined by seed germination. Journal of Biological Sciences, 4(3):288-292.

Rawat, R., Pathak, B. and Fulekar, M. H. 2018. Plant Diversity at Fly Ash Disposal Site of Thermal Power Plant Gandhinagar, Gujarat. Indian Journal of Ecology, 45(3): 528-532.

Senapati, M. R. 2011. Fly ash from Thermal Power Plants: Waste Management and overview. Current Science, 100(12):17911794.

Sharma. S. K. and Karla, N. 2006. Effect of fly ash incorporation on soil properties and productivity of crops: A review. Journal of Scientific and Industrial Research, 65:383390.

Sinha, S., Rai, U. N., Bhatt, K., Pandey, K. and Gupta, A. K. 2005. Fly-ash-induced oxidative stress and tolerance in Prosopis juliflora L. grown on different amended substrates. Environmental Monitoring and Assessment, 102: 447-457.

Subbiah, B. V. and Asija, G. L. 1956. A rapid procedure for estimation of available nitrogen in soils. Current Science, 25(8):259 -260

Walkley, A. and Black, I. A. 1934. An examination of the Degtjareff method for determining soil organic matter and a proposed modification of the chromic acid titration method. Soil Science, 37(1): 29-38.

\section{How to cite this article:}

Madhab Chandra Behera, Anil Kumar Acharya, Manas Ranjan Kar and Maoj Kumar Tripathy. 2020. Impact of Fly Ash on Germination and Initial Seedling Growth Performance of Acacia auriculiformis A. Cunn. Ex Benth. Int.J.Curr.Microbiol.App.Sci. 9(07): 2602-2610. doi: https://doi.org/10.20546/ijcmas.2020.907.307 